\section{Un paciente llamado Dr. MacKee}

Albert J. Jovell

\section{A patient called Dr. MacKee}

'Because today I'm sick. Tomorrow or 30 years from now on, you'll be sick'

Dr. Mackee to his first physician
La película El Doctor, de la directora Randa Haines, muestra cómo un médico, el Dr. MacKee -William Hurt-, experimenta en su propio hospital como paciente común el mismo trato inadecuado que daba a sus enfermos. El Dr. MacKee es un prestigioso cirujano cardiovascular que se muestra bastante insensible hacia sus pacientes hasta que sufre un tumor de laringe y descubre la importancia de los sentimientos y de la comunicación en la relación entre médicos y pacientes. El Dr. MacKee descubre con la enfermedad aquéllo que no aprendió ni en la facultad de medicina ni en su trabajo como médico: que todos los médicos acaban siendo pacientes, $\mathrm{y}$, por lo tanto, tal como tratas a tus pacientes estás enseñando a tus residentes cómo quieres ser tratado cuando tú seas el enfermo. Por eso cuando el Dr. MacKee se reincorpora al trabajo, tras su enfermedad, lo primero que hace es obligar a sus residentes a estar ingresados 72 horas como enfermos en el hospital. 'Así podréis aprender lo que nunca me explicaron a mí, les dice MacKee a sus residentes.

La historia del Dr. MacKee evidencia algunas de las contradicciones de la enseñanza de la medicina en la actualidad, sobre todo la ausencia de la participación de los pacientes en la definición de los contenidos de los planes de estudios. En una sociedad en la que, en la mayoría de los casos, los estudios de medicina son financiados un $85 \%$ de su coste por los impuestos de los ciudadanos y la mayor parte de los recién licenciados va a ejercer en el sistema público, resulta relevante conside-
The film The Doctor, directed by Randa Haines, shows how a physician, Dr. MacKee (played by William Hurt), experiences within his own hospital the same inadequate treatment he used to give his patients. Dr. MacKee is a prominent heart surgeon who is rather inconsiderate towards his patients until he suffers a throat cancer and discovers the importance of feelings and communication between physicians and their patients. Dr. MacKee learns from his disease what he didn't learn at medical school or in his years as a physician: all doctors end up being patients. And therefore, the way you deal with your patients shows your house officers how you want to be treated when you become the patient. This is why the first thing Dr. MacKee does after going back to work is to have all his house officers stay in hospital for 72 hours as patients. 'That way you can learn what they never explained to me,' MacKee says to them.

The story of Dr. MacKee highlights some of the contradictions in the teaching of medicine today, the most important of which is perhaps the fact that patients have no say when it comes to defining the contents of the curricula in medical schools. In a society in which, in most cases, $85 \%$ of the cost of medical studies is funded by taxpayers' money and most graduates are going to practise in the public health system, it seems logical to take into account citizens' opinions about what their physicians should
Director General de la Fundació Josep Laporte. Profesor Asociado de la Universitat Autònoma de Barcelona.

E-mail Albert.jovell@uab.cat 
rar las necesidades de la ciudadanía con relación a cómo deben ser sus médicos y qué necesidades son prioritarias. En cierta manera, esas necesidades ya han sido manifestadas en estudios cualitativos diversos realizados en los últimos años por autores diferentes, entre ellos los llevados a cabo en el contexto de la Universidad de los Pacientes [1]. De esta forma, tanto en la Declaración de Barcelona de las Asociaciones de Pacientes y Usuarios como en la Agenda Política del Foro Español de Pacientes se aborda el modelo de médico deseado por los pacientes en España. De hecho, el punto 5 del Decálogo indica que se solicita como derecho básico 'la formación y entrenamiento específico en habilidades de comunicación para profesionales' y el punto 17 de la Agenda Política señala que 'las facultades de medicina diseñen unos planes de estudio más orientados a responder a las necesidades de los pacientes y de la sociedad actual, que incluyan asignaturas de ética, política sanitaria, profesionalismo y comunicación médico-paciente, así como que incorporen la perspectiva del paciente en la enseñanza en las aulas' [2].

No parece existir una situación de desconfianza hacia la profesión médica en España, donde la confianza en los médicos y en las instituciones sanitarias públicas es muy alta, y es bastante superior a la expresada en otras profesiones y con instituciones pertenecientes a otros sectores diferentes de la sanidad [3]. De todas formas, vale la pena reflexionar, como bien expresa en la película el Dr. MacKee, que esta confianza se hace desde la vulnerabilidad, el miedo y la preocupación. Por eso, desconfiar de su médico o de las instituciones en las que le tratan son actitudes que un paciente no está en condiciones de asumir. Es, por lo tanto, la relación médicopaciente una relación asimétrica de poder, donde el primero tiene una gran capacidad de determinación sobre lo que le va a suceder al segundo. Y corresponde al primero, el médico, adoptar una actitud que reduzca esta asimetría. Ponerse en el lugar del paciente constituye el primer gran paso para reducir esta asimetría, que va más allá de la experiencia y el conocimiento. Ahí radica la fuerza del mensaje incluido en la película El Doctor y en el personaje de Jack MacKee.

El caso del Dr. MacKee es extremo y, tal y como él reconoce en la película, puede empezar a prevenirse si la perspectiva del paciente se adopta desde el inicio de los estudios de medicina. Es difícil dudar sobre el hecho de que la mayoría de los estudiantes que se incorporan a los estudios de primero be like and which of their needs are the most pressing. To a certain extent those needs have been voiced in different qualitative studies conducted in recent years by different authors, including those carried out within the context of the Universidad de Pacientes. [1] Thus, both the Declaración de Barcelona de las Asociaciones de Pacientes y Usuarios and the Agenda Politica del Foro Español de Pacientes deal with the model of physician desired by patients in Spain. In fact, point 5 of the 'Decalogue' calls for the following as a fundamental right: 'specific instruction and training in communication skills for professionals' and point 17 of the Agenda Politica says that 'medical schools should design curricula that are geared more towards meeting the needs of today's patients and society by including subjects on ethics, health care policy, professionalism and physician-patient communication, as well as incorporating the patient's perspective into teaching in the classroom.' [2]

There does not appear to be a general feeling of distrust towards the medical profession in Spain, where trust in physicians and public health institutions is very high, in fact quite a lot higher than that expressed with respect to other professions and institutions belonging to sectors outside the area of health care. [3] In any case, we might think that, as Dr. MacKee so well expresses in the film, this trust really stems from vulnerability, fear and worry. Patients are in no position to adopt an attitude of distrust towards their physician or the institutions that are going to treat them. The relationship of power between physician and patient is therefore asymmetrical, the former having an enormous capacity to decide on what is going to happen to the latter. And the physician is the one who must adopt an attitude that reduces this asymmetry. Putting oneself in the patient's shoes is the first great step towards making the relationship less asymmetrical, but this is something that goes beyond experience and knowledge. And therein lies the full power of the message conveyed by the film The Doctor and by its lead character.

The case of Dr. MacKee is an example taken to the extreme but, as he himself recognises in the film, we can begin to prevent similar situations if we look at things from the patient's perspective right from the beginning of our medical studies. It is difficult to question the fact that most students starting their first year at medical school do so out 
de medicina y cirugía lo hacen respondiendo a una vocación de atender y ser útil a los pacientes. El hecho de que la carrera de medicina exija más años de dedicación que otros estudios, requiera una especialización posterior a la licenciatura, obligue a una dedicación en exclusiva, tenga una nota de corte muy alta y no esté asociada a grandes ingresos económicos permite hipotetizar que los motivos por los que una persona desea estudiar medicina están asociados a una llamada vocacional.

La vocación constituye un sentimiento que se modula a lo largo del tiempo, de forma que muchas veces se puede tener la sensación de que esa llamada a responder los intereses de los enfermos es ampliada o desplazada a lo largo de los estudios de medicina y, sobre todo, en la interacción con las instituciones sanitarias hacia el diagnóstico y el tratamiento de las enfermedades. Esta movilización de los intereses vocacionales está influida por múltiples circunstancias. Así, los estudios de medicina se estructuran de forma vertical, en relación con enfermedades y especialidades, sin incorporar elementos de transversalidad o situando el estudio de los aspectos transversales en el primer ciclo de la licenciatura, cuando los estudiantes aún no han contactado con los pacientes o las instituciones sanitarias. Además, este proceso vertical condiciona a los estudiantes, de forma que éstos empiezan a pensar en 'la especialidad' que les gustaría realizar en lugar de en 'los enfermos' que les gustaría tratar.

A lo largo de los estudios de medicina y cirugía se produce una traslación del 'sujeto' hacia 'el objeto', de forma que no se tratan en primera instancia personas sino enfermedades. Este hecho se visualiza en el hospital cuando se habla del 'cáncer de páncreas' de la habitación 227 o el 'paciente terminal' del pabellón 6 en lugar de nombrar al paciente. Cómo recuerda el Dr. MacKee a uno de sus residentes 'las terminales son de autobuses' y 'mis pacientes tienen nombre y apellido'. Por otra parte, muchos estudiantes acuden a formarse a hospitales universitarios donde el modelo de éxito profesional parece estar más relacionado con la investigación que con la calidad asistencial o la docencia.

La situación expuesta de traslación vocacional se hace más patente cuando los exámenes de conocimientos realizados a los estudiantes se basan en enfermedades, en la mayoría de los casos, y les obliga a transitar por un escenario determinista que sólo suele admitir cinco posibilidades de respuesta: a, b, c, d y e. Curiosamente, la práctica de la medicina es de naturaleza probabilística, por lo of a vocation they feel to care for and to be of help to patients. The fact that a degree in medicine takes more years of study than other courses, requires specialisation after graduating, calls for full-time dedication, has a very high minimum admission GPA and is not associated with high salaries all allows us to suppose that somebody wishing to study medicine is driven primarily by a vocational calling.

Now, vocation is a feeling that changes as time goes by, so that while studying medicine or, above all, when it comes to interacting with health care institutions in matters concerning diagnoses and the treatment of diseases, one may often get the feeling that that call to aid the sick is heightened or displaced. This mobilisation of vocational interests is influenced by a number of circumstances. Furthermore, medical studies deal with diseases and specialities in a vertical manner, without including transversal elements or the study of transversal aspects in the first cycle of the degree course, when students have still not come into contact with patients or health institutions. Moreover, this vertical structure has an influence on students, who begin to think about the 'speciality' they would like to take up instead of 'the patients' that they would like to treat.

As studies in medicine and surgery progress, the focus shifts from the 'subject' towards the 'object', which means that initially doctors treat illnesses rather than people. This becomes clear in the hospital when we speak of the 'pancreatic cancer' in room 227 or the 'terminal' in ward 6, rather than referring to the actual patient. As Dr. MacKee reminds one of his house officers, 'terminals are for buses' and 'my patients have got names and surnames'. On the other hand, many students carry out their training at university hospitals, where the model of professional success seems to be far more concerned with research than with the quality of the health care or with teaching.

The situation of vocational shift described here becomes even more obvious when the exams that students must pass are, in most cases, based on diseases and force them to traverse a deterministic landscape that only usually admits five possible answers: $a, b, c, d$ and $e$. Strangely enough, medical practice is by nature probabilistic, which means that the exam system used seriously perverts the training process because it forces 
que el sistema de examen utilizado provoca una grave perversión en el proceso formativo, al obligar a los futuros médicos a pensar de forma diferente a cómo se producen los fenómenos patológicos. El sistema de examen adoptado condiciona el modo de aprendizaje y la forma de actuación delante del paciente, ya que obvia la visión panorámica de éste en su contexto al reemplazarla por parámetros analíticos y resultados de pruebas de diagnóstico por imagen. Esta visión determinista, reduccionista y algorítmica de la enfermedad, y por extensión del paciente que se tiene enfrente, puede estar asociada a sesgos y errores médicos. La mejor forma de prevenir estos últimos es entender cómo piensan los médicos y educarlos a pensar de forma crítica y panorámica [4]. La suma de detalles puede confundir la realidad.

La formación universitaria es esencial para la definición del modelo de profesionales que queremos tener. En este sentido, otro aspecto que hay que tener en cuenta en el modelo actual es la necesidad de incorporar durante la carrera un modelo de enseñanza basada en la resolución de casos clínicos y en el trabajo en equipo. No resulta apropiado ni formativo utilizar las clases para transmitir aquellos conocimientos que el alumno puede leer en los libros de texto. De hecho, la clase debería utilizarse para exponer situaciones y casos que el alumno va a encontrarse en la práctica médica cotidiana, de forma que el profesor debe orientar a los alumnos hacia el cuestionamiento crítico y a la búsqueda de respuestas. Este modelo de formación requiere de un trabajo individual, donde el rol de los tutores es crucial, y de un trabajo en grupo, ya que en la vida real los profesionales trabajan en equipo, y la aportación del conjunto suele superar a la suma de las individualidades. Este último hecho es importante ya que, tanto los estudios de medicina como la práctica profesional en España son muy individualistas y competitivos. Uno, como paciente, prefiere beneficiarse de que sean varios los que piensen sobre su caso clínico que no sólo lo haga una sola persona.

Finalmente, la reproducción de situaciones clínicas propias de la práctica cotidiana en el aula debería beneficiarse de la presencia de los propios pacientes como profesores. Por suerte, cada vez hay más pacientes que pueden aportar su experiencia como enfermos, lo que, unido a la experiencia de los médicos, constituye la mejor forma de acercarse a la excelencia terapéutica. De hecho, los pacientes también celebran en España sus congresos médicos [5]. Esta aporta- the future physicians to think differently to the way pathological phenomena are actually produced. The exam system employed conditions the way learning takes place as well as the way physicians act in the presence of their patients, since a panoramic view of the patient in his or her context is replaced by analytical parameters and the findings of diagnostic imaging tests. This deterministic, reductionistic and algorithmic view of disease, and hence of the patient we have before us, can lead to biases and medical errors. The best way to prevent such issues from appearing is to understand how doctors think and to educate them to think in a critical and far-reaching manner [4]. The sum of the details may confuse reality.

University education is essential for defining the model of professionals we want to have. And another aspect to be taken into account in the current model is the need to incorporate into the degree course a model of teaching based on clinical problem-solving and on teamwork. Using classes to impart knowledge that the student can read in a textbook is neither appropriate nor enlightening. In fact, classes should be spent on outlining situations and cases that students are going to find in their day-to-day clinical practice and the lecturer's role will therefore be to guide students towards critical inquiry and the search for answers. This model of training requires both individual work, in which the tutors play a crucial role, and group work, because in the real world professionals work as a team and the contribution made by the whole is usually greater than the sum of the individual efforts. This last fact is important because both medical studies and the professional practice of medicine in Spain are very individualistic and competitive. As a patient, we prefer to have several people thinking about our case rather than having to rely on just one single opinion.

Finally, reproducing clinical situations typically found in a physician's daily practice should include the presence of patients themselves as teachers. Fortunately, more and more patients are willing and able to contribute with their experience in hospital, and combining this with the experience of physicians is the best way to approach excellence in therapy. In fact, in Spain patients also hold their own medical conferences. [5] Thus, patients help to provide a view of the most important training needs of Spanish doctors 
ción de los pacientes permite visualizar las grandes necesidades de formación en áreas transversales (ética clínica, comunicación médico-paciente, bibliografía, profesionalismo, seguridad del paciente, duelo, calidad asistencial, política sanitaria, etc.) que tienen los médicos en España y que, en su ausencia, se encuentran más alejados de responder a las verdaderas necesidades de sus futuros pacientes. Para responder a ellas se requiere una 'educación médica orientada a los pacientes', y esto pasa por tener el coraje de querer innovar y progresar, y dar respuesta a las necesidades expresadas por aquéllos que financian gran parte de la enseñanza pública. El problema de la comodidad y la complacencia en educación médica es que convierte la formación en una actividad rígida, burocrática y menor, de manera que resulta difícil promover la excelencia en estas condiciones. Además, una sociedad democrática debería poder contemplar e implementar diferentes planes de estudios alternativos, de modo que sean los propios docentes y los estudiantes quienes elijan aquéllos que resulten más atractivos para responder a las necesidades de los pacientes. Los planes únicos en democracia sólo se entienden desde posiciones de inseguridad, miedo y autoridad malentendida. Si la sociedad y los pacientes están cambiando, la formación de médicos y los médicos también deberían hacerlo. No tendría que ser necesario padecer una enfermedad grave como el Dr. MacKee para entenderlo, aunque esa película debería verse en todas las facultades de medicina.

Dedicado al Dr. Helios Pardell (e.p.d.) por su compromiso con la mejora de la educación médica en España.

\section{Bibliografía}

1. Jovell AJ, Navarro-Rubio MD. Escuchando la voz del paciente. Gac San 2008; (Suppl 1): S192-7.

2. Disponible en: www.webpacientes.org y www.universidadpacients.org [09.12.2008].

3. Jovell AJ, Blwanson RJ, Navarro-Rubio MD, Fleischfres- in transversal areas (i.e. clinical ethics, physicianpatient communication, literature, professionalism, patient safety, mourning, quality of health care, health care policies, and so on). At the same time, in the absence of solutions to such needs, these professionals are also a long way from being capable of satisfying the real needs of their future patients. To do so, we need a 'patient-based medical education', and achieving this involves having the courage to want to innovate and progress and so meet the needs of those that fund the greater part of public education. The problem of convenience and complacency in medical education is that they turn training into a rigid, bureaucratic and less significant activity. As a result and under these conditions, it becomes difficult to promote excellence. Moreover, a democratic society should be able to contemplate and implement a number of different alternative curricula, so that members of teaching staff and students are free to choose the ones that are best suited to satisfy patients' needs. In a democracy, having a single curriculum only makes sense as something resulting from insecurity, fear and misunderstood authority. If society and patients are changing, physicians and their training should do so too. There should be no need to suffer a serious disease like Dr. MacKee in order to understand this, although that film should be shown in all medical schools.

Dedicated to the late Dr. Helios Pardell for his commitment to improving medical education in Spain. ser C, Benson JM, Dersroches CN, et al. Public trust in the Spanish Health-care system. Health Expect 2007; 10: 350-7.

4. Groopman J. How doctors think. Boston: Houghton Mifflin Company; 2007.

5. Disponible en: www.congresodepacientes.org y www. aeal.es [09.12.2008]. 